\title{
Child-centred educational practice in different early education settings: Associations with professionals' attitudes, self-efficacy, and professional background
}

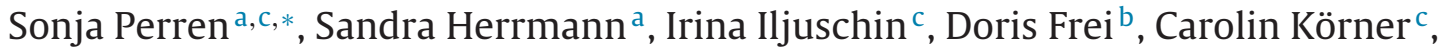 \\ Fabio Sticca ${ }^{\mathrm{a}}$ \\ a Thurgau University of Teacher Education, Kreuzlingen, Switzerland \\ ${ }^{\mathrm{b}}$ Marie Meierhofer-Institut für das Kind, Zurich, Switzerland \\ c University of Konstanz, Germany
}

Keywords:

Child-centred

Educational practice

Teacher beliefs

Attitudes

Self-efficacy

Early education

Child care

Educational settings

Professional level

Professional experience

\begin{abstract}
A B S T R A C T
The present study investigated whether teacher beliefs (self-efficacy and attitudes) mediate the impact of professional background on child-centred educational practice. We specifically investigated whether teacher beliefs related to self (self-efficacy) are a stronger predictor of educational practice than teacher beliefs related to teaching approach (attitudes). A total of 265 professionals from different early education and care settings (i.e., centre-based daycare, family-based daycare, and educational playgroups) in Switzerland participated in the study. A self-report questionnaire was developed to assess professionals' self-efficacy, attitudes and educational practice in terms of child-centredness. The results confirm the factorial validity of the questionnaire. Self-efficacy positively predicted educational practice, while professionals' attitudes were not associated with educational practice. Further, the positive effect of domain-specific knowledge on educational practice was mediated by self-efficacy. Finally, family daycare providers reported lower self-efficacy and lower levels of child-centred educational practice than other professionals. The present study emphasises the role of professionals' self-efficacy in the context of delivering high-quality childcare and child-centred education in early childhood. The results suggest that promoting knowledge of teaching approaches may be a promising way to promote early childhood educators' child-centred educational practice through increasing their self-efficacy.
\end{abstract}

Effective early childhood education is thought to promote children's learning and development and also to contribute to children's mental health. Child-centred educational practices are characterised by an understanding of effective promotion of children's learning and development considering children's individual needs and developmental level (Copple \& Bredekamp, 2010). Childcentred teaching practices also indicate high process quality in early education and care, for example through a strong consideration of child perspectives or a high quality of feedback in response to what children do or say (La Paro, Hamre, \& Pianta, 2012). Professional development (through education, certification or training) is considered to be an important factor in fostering developmen-

* Corresponding author at: Thurgau University of Teacher Education and University of Konstanz, Chair of Development and Education in Early Childhood, Bärenstrasse 38, 8280 Kreuzlingen, Switzerland.

E-mail address: sonja.perren@uni-konstanz.de (S. Perren). tally appropriate educational practices in early education settings (Sheridan, Edwards, Marvin, \& Knoche, 2009). One of the mechanisms through which professional level and experience may have an impact on educational practice is through teacher beliefs (Fives \& Buehl, 2012). The current study aims to investigate whether teacher beliefs (self-efficacy and attitudes) mediate the impact of professional background on educational practice in different educational and care settings in Switzerland.

\section{Early education and care in Switzerland}

In German-speaking Switzerland, early education and care for children aged under four years takes place in different types of care settings: centre-based daycare, family-based daycare, and educational playgroups (Perren, Frei, \& Herrmann, 2016). At four years old, most children will transition to mandatory kindergarten, which is a well-established part of the Swiss school system with structures and teachers' professional level paralleling the school system. 
In contrast, early childhood education and care lacks such clear structures and caregivers and educators have heterogeneous professional levels.

\subsection{Centre-based daycare}

Daycare centres are institutions which are open full-time on all five weekdays and provide daycare for children from infancy up to about four years of age (Stamm, 2009). In contrast to other countries, in Switzerland most children attend daycare only part-time, generally 2-3 days per week (Bundesamt für Statistik, 2014). Due to recent developments within the field and a new emphasis on daycare quality, daycare centres are now also understood as important educational institutions that foster children's learning and development. However, only a minority of children attends centre-based daycare.

Professional caregivers in centre-based daycare most often complete an apprenticeship. This is a dual vocational training of three years, which comprises two-day school attendance and three-day in-service training per week. Professional caregivers only rarely have a college or university degree. In daycare centres, a high percentage of trainees (i.e., young persons who attend a first year-long internship after completion of mandatory school) and apprentices work alongside trained professional caregivers (Stamm, 2009).

\subsection{Family-based daycare}

As in many other countries, family daycare is provided by individual caregivers in their own homes. As family daycare offers flexible daycare arrangements, many parents choose this form of daycare. Family daycare providers are often self-employed workers, but they are frequently affiliated to a network of childcare workers or an association of daycare homes. Most daycare home associations expect some basic training before they will engage staff. The minimum requirement is $18 \mathrm{~h}$ of training and a six-hour first aid course for small children, plus at least three hours of further training per year. Apart from these recommendations, no formal requirements exist. Thus, the professional backgrounds of family daycare providers are very heterogeneous (Stamm, 2009).

\subsection{Educational playgroups}

Many children aged between three and four years attend an educational playgroup one to three times a week for about two to four hours at a time. Unlike other daycare institutions, educational playgroups primarily have educational aims and do not aim to provide daycare for the children of working parents (Stamm, 2009). There is no formally or nationally acknowledged education or certification procedure, and there are no official requirements for the educational level or training of playgroup educators either (i.e., any individual can open a playgroup). However, the Swiss Association of Playgroup Educators (Schweizerischer Spielgruppen-LeiterinnenVerband, www.sslv.ch) has drawn up standardised guidelines (www.sslv.ch) to promote a certain level of quality. Passing basic training of $80-100 \mathrm{~h}$ qualifies a person to organise and start an educational playgroup. However, this training is not mandatory. Thus, the professional background and general education level of playgroup teachers is very heterogeneous (Stamm, 2009).

\subsection{Child-centred educational practice in Switzerland}

As indicated above, the educational level of early childhood professionals for zero- to four-year-old children in Switzerland is quite low (Stamm, 2009). Different stakeholders have initiated a series of activities for professional development in recent years. One of these activities were to draw up a central reference document that aims to enhance professionals' knowledge of child-centred educational practice (Orientierungsrahmen; Wustmann Seiler \& Simoni, 2012). The Orientierungsrahmen can be freely downloaded from www. orientierungsrahmen.ch and is meant to enhance child-centred educational practice in different care and educational settings. Its foundation is a relationship-focused approach that favours strongly child-centred education. In line with this reference document, we understand child-centred practice as an educational practice that allows children autonomously - supported when necessary - to explore their environment, to build and consolidate their competences, to benefit from various and stimulating learning opportunities, and to be valued and respected as members of the community. The Orientierungsrahmen is currently being used in the field to promote professional development through dissemination of the document itself, related publications, round table discussion, specific training opportunities, workshops, conferences, and a website with demonstration videos (www.kinder-4.ch).

\section{Professional background and educational practice and teacher beliefs}

In the current study, the term professional background includes both professional level (i.e., training in early childhood education, acquisition of domain-specific knowledge, and formal educational level) and professional experience. Associations between these different aspects of professional background and educational practice and teacher beliefs have been examined in a number of studies.

\subsection{Educational practice}

Findings about the effect of early childhood educators' training on their educational practice are rather complex. Training, such as workshops or professional meetings, is understood as professional development that does not confer credits for a higher educational degree. In their meta-analysis of the relevant research studies on the topic, Fukkink and Lont (2007) found a positive association between childcare workers' participation in training and higher programme quality or more sensitive interactions with children. Although training in general may increase the quality of educational practice, the effects differ according to some features of the training. In particular, training was more effective if it was continuous or renewed intermittently, was sequential, and followed a fixed curriculum.

Formal educational attainment of early childhood educators is commonly measured by years of education, by the highest degree obtained, and by holding a degree in related fields of early childhood education. Some studies found positive associations between formal education and higher observed quality of educational practice in preschool classrooms (Guo, Piasta, Justice, \& Kaderavek, 2010; Tout, Zaslow, \& Berry, 2005). However, other studies found no consistent association (Early et al., 2007). The review by Zaslow, Tout, Halle, Whittaker, and Lavelle (2010) identified individualised professional development as a promising but not completely confirmed approach to improving educational practice. The most effective approaches aim to enhance professionals' knowledge through theoretical coursework, combined with individualised training in interaction skills (caregiver-child) and feedback on such skills (Zaslow et al., 2010).

Professional experience is also an important part of professional background. For example, a study of preschool children showed that years of educators' professional experience is positively associated with observed emotional and instructional support (Jeon, Buettner, \& Hur, 2015). In summary, professional background (i.e., higher education or training, or more professional experience) may have a positive impact on educational practice. 


\subsection{Teacher beliefs}

Professional background has also been shown to be associated with teacher beliefs (e.g., attitudes and self-efficacy). For instance, a recent German study showed that training aimed at enhancing early childhood teachers' educational competences positively influenced both their attitudes and their educational practice (Weltzien, 2011). Teacher self-efficacy can improve through attending courses (Ross \& Bruce, 2007; Swackhamer, Koellner, Basile, \& Kimbrough, 2009). Beliefs can also change over the course of a professional career. This has been demonstrated in research into development in preservice teachers (Fives \& Buehl, 2012). Years of teaching experience seem to be positively associated with self-efficacy related to classroom management in preschool teachers (Bullock, Coplan, \& Bosacki, 2015). A large international study (TALIS: Teaching and Learning International Survey) showed that in half of the participating countries, years of teaching experience was positively associated with schoolteachers' self-efficacy, structured teaching practices, and student-oriented teaching practices (OECD: Organisation for Economic Co-operation and Development, 2009).

In sum, some studies showed that education or training can alter teachers' beliefs and their educational practice. But only few studies investigated the interplay between these factors in early childhood education.

\section{Teacher beliefs and educational practice}

Teacher beliefs are considered to be an important factor explaining individual differences in teachers' educational practice. Fives and Buehl (2012) reviewed the multi-faceted research on teacher beliefs and developed a theoretical framework.

\subsection{Conceptualisation and functions of teacher beliefs}

There are numerous different conceptualisations and definitions of teacher beliefs. As Fives and Buehl (2012) reviewed, many different aspects of teacher beliefs have been investigated, leading to an incoherent research field. Teacher beliefs have even be considered as a "messy construct" (Pajares, 1992). Fives and Buehl (2012) suggested differentiating between teacher beliefs about (a) self, (b) context or environment, (c) content or knowledge, (d) specific teaching practices, (e) teaching approach, and (f) students. In our study, we focus on and differentiate between teacher beliefs about the self (i.e., self-efficacy in child-centred education), which will be referred to below as "self-efficacy", and beliefs about teaching approach (i.e., about child-centred education), which will be referred to below as "attitudes". "Beliefs" is used as an umbrella term.

It is generally believed that teacher beliefs have an impact on teachers' educational practice. As Fives and Buehl (2012) suggested, it is important to uncover the specific mechanisms and processes that explain how beliefs function for teachers engaged in practice. According to their suggestion, beliefs can act as filters (i.e., interpretation of events as relevant), as frames (i.e., definition of a problem or task), or as guides (i.e., motivations which immediately affect action). Fives and Buehl (2012) argued that attitudes toward teaching approach (which corresponds to child-centred educational practice in our study) may act as filters or frames, whereas self-efficacy beliefs may act as guides. Beliefs that act as filters are related to behaviour because they influence perception and the interpretation of information and experience. For example, in the study by Suk Lee, Baik, and Charlesworth (2006), attitudes towards developmentally appropriate practice moderated the impact of training on the use of scaffolding in preschool teachers
(Suk Lee et al., 2006). Only those teachers who endorsed developmentally appropriate practices showed gains in their teaching strategies. Furthermore, beliefs (such as attitudes towards learning approaches) may also act as frames, that is they play a role in the way teachers conceptualise the problem at hand (Fives \& Buehl, 2012). Beliefs related to self (i.e., teachers' self-efficacy) are considered as motivational constructs that guide teachers' goals, their effort to achieve those goals, and their perseverance and task engagement (Fives \& Buehl, 2012).

\subsection{Self-efficacy and educational practice}

Teacher beliefs related to self have mainly been investigated in relation to teachers' self-efficacy. There is a large research field investigating the role of self-efficacy in individuals' behaviour and well-being. According to Bandura (1977, 1986, p. 391), "perceived self-efficacy is defined as people's judgments of their capabilities to organise and execute courses of action required to attain designated types of performance". Accordingly, teachers' self-efficacy is defined as the extent to which teachers feel able to influence their students' learning abilities and performance (TschannenMoran, Hoy, \& Hoy, 1998). Teachers who consider themselves as self-effective invest more effort in teaching, persist longer when faced with obstacles and adopt more innovative teaching methods (Tschannen-Moran et al., 1998). Most studies of teacher self-efficacy refer to teachers of school-aged children, but a few studies also included early childhood teachers. A questionnaire completed by 584 preschool, kindergarten, and first grade teachers showed that teachers with higher self-efficacy spent more time communicating with parents and teaching both cognitive and social-emotional skills (Fantuzzo et al., 2012). In contrast, a study that examined the relationship between preschool teachers' self-efficacy, attitudes, and observed instructional practice in mathematics did not support the relation between self-efficacy and practice (Todd Brown, 2005).

Taken together, the research suggests that self-efficacy is a relevant factor in explaining individuals' behaviour and teaching practice. However, no study has specifically addressed the role of self-efficacy in terms of child-centred educational practice.

\subsection{Attitudes and educational practice}

The relationship between early childhood teachers' attitudes towards educational concepts and their educational practice has interested researchers for a long time, and the association seems to be well established. Several studies found that attitudes towards child-centredness (e.g., authority sharing or developmentally appropriate practice) were associated with the observed or reported use of more child-centred teaching strategies (e.g., Charlesworth et al., 1993; Stipek \& Byler, 1997; Suk Lee et al., 2006). More recent research underlines the documented relationship between attitudes and educational practice: early childhood care providers whose attitudes were more in line with developmentally appropriate practice provided care of overall higher quality and showed more sensitivity (Hughes-Belding, Hegland, Stein, Sideris, \& Bryant, 2012). They also emphasised child-directed choice/play as well as emergent literacy and language development activities more frequently than traditional teachers (McMullen et al., 2006). In contrast, preschool teachers who held more traditional or academic-oriented beliefs were more likely to promote routines, organised classrooms, a preplanned curriculum, and teacher-directed learning (McMullen et al., 2006). A recent study also demonstrated that child-centred attitudes may have an impact on children's academic achievement through improved self-regulation (Hur, Buettner, \& Jeon, 2015). In sum, child-centred 
attitudes have a positive impact on developmentally appropriate practice in early childhood education.

The current state of research therefore more or less consistently suggests that early childhood teachers' professional level and experience as well as teacher beliefs may affect their educational practice. Based on research findings and the theoretical framework by Fives and Buehl (2012), it can be concluded that both attitudes and self-efficacy are important when it comes to establishing and maintaining child-centred educational practice in early education settings. In particular, professional level has been shown to be positively associated with teacher beliefs, which were in turn shown to be positively associated with educational practice. Therefore, teacher beliefs may act as mechanisms effecting teacher behaviour However, there is a lack of studies investigating the mechanisms underlying the association between professional background and educational practice in early childhood education and care. Specifically, no study has yet investigated whether teacher beliefs (i.e., self-efficacy and attitudes) regarding child-centred educational practice mediate the association between professional level and child-centred educational practice.

\section{Research questions and hypotheses}

This study aimed to investigate the effect of professional background on child-centred educational practice in different care and education settings. We specifically investigate the role of teacher beliefs (self-efficacy and attitudes) as potential mediators between professional level and experience and practice. The theoretical framework of this study draws on the work of Fives and Buehl (2012). According to this framework, attitudes toward teaching approach (in our study, in terms of child-centred educational practice) may act as filters or frames, whereas self-efficacy may act as a guide for educators' practice. As self-efficacy is more closely related to the immediate action we hypothesise that the impact of self-efficacy on educational practice is stronger than the impact of attitudes towards teaching approach.

First, we report bivariate associations between professionals' attitudes, self-efficacy and educational practice. Second, we investigate the role of different facets of professional background (i.e., domain-specific knowledge, professional experience, training in early childhood education, and educational level) on child-centred educational practice. As the field of early education and care in Switzerland consists of educators with heterogeneous professional backgrounds who work in different settings (daycare centres, family care and educational playgroups), we also investigated the role of the educational setting on child-centred education. Finally, we report the results of multivariate analyses which specifically investigate the hypothesised mediation paths.

\section{Method}

\subsection{Procedure}

To address our research aims, we conducted an online survey of a heterogeneous sample of professionals working in early care and educational settings. We recruited these participants through professional networks for early education and care in the Germanspeaking part of Switzerland. Members of the networks received an email with a short description of the study goals and an invitation to participate by following a link to the online survey. Participants were encouraged to spread the link to their colleagues. Participation was voluntary and 30 gift certificates (EUR 30 each) were raffled among participants after completion of data collection. This recruitment strategy resulted in a convenience sample. As there is currently no official record of the population of professionals working in early care and educational settings in Switzerland, no information on the representativeness of the sample can be provided.

Participants gave information on their educational settings and professional background, and completed a questionnaire that was developed for the present study in order to assess early childhood professionals' attitudes, self-efficacy, and educational practice (see below). The sections of the core questionnaire (i.e., attitudes, selfefficacy, and educational practice) were presented in a random order to prevent systematic and selective patterns of partial completion, sequence effects, and fatigue effects.

Data were included for analysis if full information on educational and professional background was provided and at least one section of the core questionnaire had been completed successfully.

\subsection{Participants}

A total of 265 caregivers and educators of zero- to four-yearold children from different Swiss early educational settings (96\% females, age: $M=38.5, S D=10.9$ ) participated in the present study. A total of $78.5 \%$ of the participants were Swiss citizens, $17.7 \%$ were German citizens, and 3.8\% had another nationality.

\subsubsection{Educational setting}

Ninety-six participants worked in centre-based daycare, 50 participants worked in family-based daycare, 86 participants led educational playgroups, and 33 worked in other educational or care settings. On average, participants worked $21.4 \mathrm{~h}$ per week with children $(S D=15.3)$ in an educational setting. For the analyses reported in the results section, the variable educational setting was either used as categorical variable (bivariate analyses) or dummy coded with centre-based daycare as a reference category (multivariate analyses).

\subsubsection{Group size}

The average group size across all educational settings was $11.4(S D=8.9)$, with an average child-caregiver ratio of 4.6 $(S D=2.4)$. Significant education setting differences were found with respect to the group size. The group size in daycare centres was largest $(M=15.96, S D=11.58)$, followed by educational playgroups $(M=10.5, S D=3.76)$, and the groups in family daycare were smallest $(M=5.46, S D=4.45)$. This variable is used as a control variable in the statistical analyses.

\subsubsection{Length of training in early childhood education}

Participants had completed an average 21.2 months of training in early childhood education $(S D=20.2)$. For later analyses, the number of months of training in early childhood education was used as an indicator of training in early childhood education.

Participants in the different early education settings showed significant differences in their length of training in early childhood education (Wald $\chi^{2}(261)=26.16 ; p<0.001$ ). Professionals working in centre-based daycare $(M=26.1, S D=21.1)$ reported significantly more months of training than those providing family-based daycare $(M=9.4, S D=15.9 ; T(145)=4.97 ; p<0.001 ; d=0.83)$ and professionals leading educational playgroups $(M=21.3, S D=18.4)$ also reported a longer duration of training than those in family-based daycare $(T(134)=3.45 ; p<0.01 ; d=0.60)$.

\subsubsection{Professional experience}

Participants had worked professionally with children for an average of 13.5 years $(S D=10.5)$. For later analyses, the number of years of professional work with children was used as an indicator of professional experience. No significant differences regarding pro- 
fessional experience were found between the different education settings.

\subsubsection{Educational level}

In terms of their general education level, 109 of the participants held a degree from a technical college, a university of applied sciences, or a university $(=2)$, while 135 had completed professional education (e.g., vocational training) $(=1)$, and 21 had no degree or were still in education at the time of participation $(=0)$. For later analyses, educational level was coded as a linear variable, with higher scores indicating higher educational level. No significant differences in general education level were found between the different educational settings.

\subsubsection{Domain-specific knowledge}

Participants also indicated their domain-specific knowledge of the Orientierungsrahmen (reference document as described above; Wustmann Seiler \& Simoni, 2012). Of the participants, 127 did not know it at all $(=0)$, while 47 only had a brief look at it $(=1), 60$ did read it $(=2)$, and 31 reported that they have actively engaged with its content $(=3)$. For later analyses, the domain-specific knowledge was coded as a linear variable, higher scores indicating more domainspecific knowledge $(M=0.98, S D=1.09)$.

For domain-specific knowledge, significant differences between early educational settings were found (Wald $\chi^{2}(265)=11.92$; $p<0.01)$. Professionals leading an educational playgroup $(M=1.21$, $S D=1.13$ ) reported more domain-specific knowledge than those providing family-based daycare $(M=0.56, S D=0.81 ; T(136)=3.45$ $p<0.01 ; d=0.60)$. No other significant differences in domainspecific knowledge were found (centre-based daycare: $M=1.00$, $S D=1.01$.

\subsection{Development of the ORA questionnaire}

A self-report questionnaire was developed to assess childcentredness in professionals' attitudes, self-efficacy, and educational practice (Perren \& Herrmann, 2014). The questionnaire is based on the Orientierungsrahmen ("ORA") (Wustmann Seiler \& Simoni, 2012). The full questionnaire also includes additional scales covering the caregiver-child relationship (e.g., sensitivity) and specific educational strategies (e.g., observation and documentation). These scales are not described here, since the scope of the paper is restricted to child-centred educational practice and related teacher beliefs.

The ORA questionnaire consists of three domains, namely professionals' self-efficacy, attitudes, and educational practice. Each of these three domains referred to a child-centred teaching approach and contained three subscales: child participation (CP), child as an active learner $(\mathrm{AL})$, and learning environment $(\mathrm{LE})$. The subscale child participation describes the extent to which each child is seen as an individual and is appreciated and included in his or her uniqueness. Professionals who score highly on child participation make efforts to ensure that each child has a place in the community and that children's concerns are taken seriously. Furthermore, such professionals create daily life together and on a level with children. The subscale child as active learner describes the extent to which professionals consider children to be active learners and therefore allow children autonomously to explore and interact with their environment. Professionals with high scores on this scale enable children to connect new experiences to previous knowledge and to find their own ways of overcoming obstacles and solving problems. The subscale learning environment describes the extent to which professionals create a stimulating and versatile learning environment for children. Professionals high on this scale offer varying, inspirational, and developmentally appropriate toys and learning materials to children, and encourage their use.
All questionnaire items were revised by field experts and confirmed to be face valid in terms of child-centredness.

\subsubsection{Self-efficacy}

Professionals' self-efficacy was assessed in line with Bandura's social cognitive theory (Bandura, 1997; Schwarzer, 1992) following explicit rules for item phrasing: items start with $I$ (i.e., subjective beliefs of the respondent are the focus), express abilities or skills (e.g., can or am able to), and contain some kind of difficulty in performing the described action (e.g., even though) or require an explicit resource that is needed to perform the specified task. This domain contained 18 items that described self-efficacy towards child-centredness. Each subscale (i.e., CP, AL, and LE) was represented by six items. Participants were asked to indicate their agreement with the statements, with response options ranking from $1=$ totally disagree to $5=$ totally agree so that high ratings indicated greater self-efficacy.

\subsubsection{Attitudes}

Participants were asked to rate 18 attitude statements tapping into a child-centred teaching approach. Each subscale (i.e., CP, AL, and LE) was represented by six statements. Participants were asked to indicate how these statements matched their own attitudes. Response options ranged from $1=$ totally disagree to $5=$ totally agree . Negatively worded items were reversed. Thus, high ratings indicated attitudes favouring a child-centred teaching approach.

\subsubsection{Educational practice}

This domain contained 15 items describing educational practices. Each subscale (i.e., CP, AL, and LE) was represented by five items. Participants were asked to rate how often they showed the described practice in their daily work with children. Rating options ranked from $1=$ never to $5=$ always with high ratings indicating a high frequency of child-centred educational practices.

\subsection{Item selection and examination of the factorial structure of the ORA questionnaire}

In the first version of the ORA questionnaire, all constructs were represented by five to six items. For the further use of the questionnaire, we aimed to develop a short version. Thus, in a first step the best fitting items were selected and the factorial validity of the questionnaire was tested. The items of the short (final) version of the ORA questionnaire are listed with their original German phrasing and their English translations in Table 1 (educational practice), Table 2 (attitudes), and Table 3 (self-efficacy).

\subsubsection{Item selection}

In a first step, the number of items was reduced to shorten the questionnaire so that further use of the ORA questionnaire was more practical. To identify the items that were most representative of the respective subscale (i.e., $\mathrm{CP}, \mathrm{AL}$, and LE), confirmatory factor analyses were run separately for each domain. Within each domain, we aimed to retain three items for each subscale, resulting in a total of nine items for each domain. For educational practice and self-efficacy, we were able to retain nine items. For attitudes, we retained only eight items (see Table 2 ) because the other items showed weak factor loadings.

\subsubsection{Factorial structure}

In a next step, all factors were entered into the same model to investigate the factorial structure of the short version of the questionnaire. A first-order measurement model was produced for attitudes, self-efficacy, and educational practice. The items of the three subscales were averaged and used as indicators of the respective latent variable representing the domain. This modelling 
Table 1

Questionnaire Items for Educational Practice.

\begin{tabular}{|c|c|c|c|c|c|}
\hline & \multirow[t]{2}{*}{ Original item (German) } & \multirow[t]{2}{*}{ Translation (English) } & \multicolumn{3}{|c|}{ Subscales (topics) } \\
\hline & & & $\mathrm{CP}$ & AL & $\overline{\mathrm{LE}}$ \\
\hline E_CP01 & $\begin{array}{l}\text { Ich achte darauf, dass jedes Kind seinen } \\
\text { Beitrag zum Gruppenalltag leisten kann. }\end{array}$ & $\begin{array}{l}\text { I take care that each child can contribute to } \\
\text { the daily group routines. }\end{array}$ & $\mathrm{x}$ & & \\
\hline E_CPO3 & $\begin{array}{l}\text { Ich beziehe Kinder in alltägliche Aufgaben } \\
\text { wie z.B. Tisch decken oder Putzen mit ein, } \\
\text { auch wenn ich es alleine schneller } \\
\text { erledigen könnte. }\end{array}$ & $\begin{array}{l}\text { I involve children in daily tasks such as } \\
\text { setting the table or cleaning, even if I could } \\
\text { handle them faster myself. }\end{array}$ & $\mathrm{x}$ & & \\
\hline E_CPO4 & $\begin{array}{l}\text { Von den Ideen der Kinder lasse ich mich } \\
\text { immer wieder inspirieren und setze ihre } \\
\text { Ideen mit ihnen um. }\end{array}$ & $\begin{array}{l}\text { I always let children's ideas inspire me and } \\
\text { realise their ideas together with them. }\end{array}$ & $\mathrm{x}$ & & \\
\hline E_AL01 & $\begin{array}{l}\text { Wenn ein Kind etwas ausprobiert, dann } \\
\text { helfe ich nur, wenn es selber nicht mehr } \\
\text { weiter kommt. }\end{array}$ & $\begin{array}{l}\text { If a child is trying something out, I help } \\
\text { only if he or she cannot proceed on their } \\
\text { own. }\end{array}$ & & $\mathrm{x}$ & \\
\hline E_AL03 & $\begin{array}{l}\text { Ich gebe den Kindern die Möglichkeit, } \\
\text { selber auszuprobieren und ihre Umgebung } \\
\text { zu erkunden. }\end{array}$ & $\begin{array}{l}\text { I give children the opportunity to try } \\
\text { something on their own and to explore } \\
\text { their surroundings. }\end{array}$ & & $\mathrm{x}$ & \\
\hline E_AL06 & $\begin{array}{l}\text { Ich lasse Kindern Zeit, Schwierigkeiten zu } \\
\text { bewältigen, und biete ihnen nur soviel } \\
\text { Hilfestellung wie nötig, um selber ans Ziel } \\
\text { zu kommen. }\end{array}$ & $\begin{array}{l}\text { I give children time to handle difficulties } \\
\text { and only offer as much help as they need to } \\
\text { succeed by themselves. }\end{array}$ & & $\mathrm{x}$ & \\
\hline E_LE01 & $\begin{array}{l}\text { Ich stelle den Kindern vielseitige und frei } \\
\text { zugängliche Materialien zum Entdecken } \\
\text { und Erforschen zur Verfügung. }\end{array}$ & $\begin{array}{l}\text { I provide diverse and freely accessible } \\
\text { materials for the children to discover and } \\
\text { explore. }\end{array}$ & & & $\mathrm{x}$ \\
\hline E_LE02 & $\begin{array}{l}\text { Ich zeige Kindern immer wieder neues } \\
\text { Spiel- und Lernmaterial und ermutige sie, } \\
\text { dieses auszuprobieren. }\end{array}$ & $\begin{array}{l}\text { I show children new toys and learning } \\
\text { material again and again and encourage } \\
\text { them to try them out. }\end{array}$ & & & $\mathrm{x}$ \\
\hline E_LE06 & $\begin{array}{l}\text { Ich passe die Lernumgebung immer wieder } \\
\text { den aktuellen Interessen und Bedürfnissen } \\
\text { der Kinder an. }\end{array}$ & $\begin{array}{l}\text { I continually adapt the learning } \\
\text { surroundings to the children's current } \\
\text { interests and needs. }\end{array}$ & & & $\mathrm{x}$ \\
\hline
\end{tabular}

Note: $\mathrm{CP}=$ Child participation; $\mathrm{AL}=\mathrm{Child}$ as Active Learner; $\mathrm{LE}=$ Learning Environment.

Table 2

Questionnaire Items for Attitudes.

\begin{tabular}{|c|c|c|c|c|c|}
\hline & \multirow[t]{2}{*}{ Original item (German) } & \multirow[t]{2}{*}{ Translation (English) } & \multicolumn{3}{|c|}{ Subscales (topics) } \\
\hline & & & $\mathrm{CP}$ & $\mathrm{AL}$ & LE \\
\hline A_CP02 & $\begin{array}{l}\text { Die Ideen der Kinder sind eine sehr grosse } \\
\text { Bereicherung für den Betreuungsalltag. }\end{array}$ & $\begin{array}{l}\text { The children's ideas are a very great } \\
\text { enrichment to the daily care routines. }\end{array}$ & $\mathrm{x}$ & & \\
\hline A_CP03 & $\begin{array}{l}\text { Wenn Kinder bei alltäglichen Aufgaben } \\
\text { mithelfen, bekommen sie das Gefühl, dass } \\
\text { sie wichtig sind und einen Beitrag leisten } \\
\text { können. }\end{array}$ & $\begin{array}{l}\text { If children help with daily tasks they can } \\
\text { feel important and able to contribute. }\end{array}$ & $\mathrm{x}$ & & \\
\hline A_CP05 & $\begin{array}{l}\text { Bereits kleine Kinder suchen die } \\
\text { Anerkennung in der Gemeinschaft. }\end{array}$ & $\begin{array}{l}\text { Even young children seek the acceptance } \\
\text { of the community. }\end{array}$ & $\mathrm{x}$ & & \\
\hline A_AL03 & $\begin{array}{l}\text { Kinder lernen, indem sie Dinge selber } \\
\text { machen und ausprobieren. }\end{array}$ & $\begin{array}{l}\text { Children learn by doing and trying things } \\
\text { out by themselves. }\end{array}$ & & $\mathrm{x}$ & \\
\hline A_AL04 & $\begin{array}{l}\text { Kinder müssen Neues mit ihren bisherigen } \\
\text { Erfahrungen verbinden können. }\end{array}$ & $\begin{array}{l}\text { Children need to connect new experiences } \\
\text { to previous ones. }\end{array}$ & & $\mathrm{x}$ & \\
\hline A_LE01 & $\begin{array}{l}\text { Aufgabe des Erwachsenen ist es, den } \\
\text { Kindern Umgebungen und Tagesabläufe } \\
\text { zur Verfügung zu stellen, in denen sie } \\
\text { vielfältige Erfahrungen sammeln können }\end{array}$ & $\begin{array}{l}\text { It is the adults' task to provide children } \\
\text { with surroundings and daily routines that } \\
\text { allow them to gather diverse experiences. }\end{array}$ & & & $\mathrm{x}$ \\
\hline A_LE02 & $\begin{array}{l}\text { Fachpersonen sollen den Kindern auch } \\
\text { Spielsachen und Materialien anbieten, die } \\
\text { sie noch nicht kennen. }\end{array}$ & $\begin{array}{l}\text { Childcare workers should offer children } \\
\text { toys and materials with which they are not } \\
\text { yet familiar. }\end{array}$ & & & $\mathrm{x}$ \\
\hline A_LE04 & $\begin{array}{l}\text { Die Lernumgebung muss Kindern } \\
\text { ermöglichen, eine Situation mit allen } \\
\text { Sinnen zu erfassen. }\end{array}$ & $\begin{array}{l}\text { The learning environment needs to allow } \\
\text { children to perceive a situation with all } \\
\text { their senses. }\end{array}$ & & & $\mathrm{x}$ \\
\hline
\end{tabular}

Note: $\mathrm{CP}=$ Child participation; $\mathrm{AL}=$ Child as Active Learner; $\mathrm{LE}=$ Learning Environment.

strategy was chosen in order to reduce model complexity and because a just-identified latent variable (i.e., with three indicators) is to be preferred to an over-identified latent variable (i.e., with more than three indicators) (Little, Cunningham, Shahar, \& Widaman, 2002). This strategy is appropriate to our data since the subscales equally represent the multiple aspects of each scale, which in turn means that requirements for parcelling are met (Kishton \& Widaman, 1994).
Results obtained from confirmatory factor analysis confirmed the hypothesised factorial structure of the short version of the questionnaire. The model described above showed a good fit to the data $\left(\chi^{2}=45.1 ; d f=24 ; p<0.01 ; C F I=0.96\right.$; RMSEA =0.058; SRMR $=0.036$ ). Given that the items of the subscales had substantial similarity in phrasing, we decided to allow the residuals of similarly worded items to correlate. The model with residual corre- 
Table 3

Questionnaire Items for Self-Efficacy.

\begin{tabular}{|c|c|c|c|c|c|}
\hline & \multirow[t]{2}{*}{ Original item (German) } & \multirow[t]{2}{*}{ Translation (English) } & \multicolumn{3}{|c|}{ Subscales (topics) } \\
\hline & & & $\mathrm{CP}$ & $\mathrm{AL}$ & LE \\
\hline $\mathrm{S} \_\mathrm{CP} 02$ & $\begin{array}{l}\text { Ich kann die Anliegen der Kinder erfragen } \\
\text { und berücksichtigen, auch wenn die } \\
\text { Kinder sehr schüchtern sind oder noch } \\
\text { nicht gut sprechen können. }\end{array}$ & $\begin{array}{l}\text { I can ask about children's concerns and } \\
\text { respect them, even if the children are very } \\
\text { shy or cannot yet speak fluently. }\end{array}$ & $\mathrm{x}$ & & \\
\hline S_CP04 & $\begin{array}{l}\text { Ich zeige Interesse für die Ideen der Kinder } \\
\text { und nehme diese auf, auch wenn ich lieber } \\
\text { ein anderes Programm durchgeführt hätte. }\end{array}$ & $\begin{array}{l}\text { I show interest in children's ideas and } \\
\text { incorporate them, even though I'd rather } \\
\text { follow another programme. }\end{array}$ & $\mathrm{x}$ & & \\
\hline S_CP05 & $\begin{array}{l}\text { Ich kann mich für die Meinungen und } \\
\text { Ansichten der Kinder interessieren und } \\
\text { diese im Betreuungsalltag berücksichtigen, } \\
\text { auch wenn ich unter Zeitdruck stehe. }\end{array}$ & $\begin{array}{l}\text { I can be interested in children's opinions } \\
\text { and views and consider them, even if I'm } \\
\text { under time pressure. }\end{array}$ & $\mathrm{x}$ & & \\
\hline S_AL01 & $\begin{array}{l}\text { Ich bin dazu fähig, Kinder in ihrer } \\
\text { selbstständigen Erkundung der Umgebung } \\
\text { zu unterstützen, auch wenn die Kinder } \\
\text { ängstlich sind. }\end{array}$ & $\begin{array}{l}\text { I'm able to support children in their } \\
\text { autonomous exploration of the } \\
\text { environment, even when children are } \\
\text { anxious. }\end{array}$ & & $\mathrm{x}$ & \\
\hline S_AL02 & $\begin{array}{l}\text { Ich kann interessierter Zuschauer sein } \\
\text { ohne zu helfen, auch wenn ich ungeduldig } \\
\text { werde. }\end{array}$ & $\begin{array}{l}\text { I can show interest as an observer without } \\
\text { intervening, even when I get impatient. }\end{array}$ & & $\mathrm{x}$ & \\
\hline S_AL03 & $\begin{array}{l}\text { Ich kann aushalten, wenn Kinder Dinge auf } \\
\text { ihre Art angehen, auch wenn ich eine } \\
\text { bessere Lösung kenne. }\end{array}$ & $\begin{array}{l}\text { I can tolerate the children approaching } \\
\text { things in their own way, even if I know a } \\
\text { better solution. }\end{array}$ & & $\mathrm{x}$ & \\
\hline S_LE01 & $\begin{array}{l}\text { Ich kann vielseitige Spielräume und } \\
\text { Materialien zu Verfügung stellen, auch } \\
\text { wenn die Ressourcen der Institution } \\
\text { beschränkt sind. }\end{array}$ & $\begin{array}{l}\text { I can provide diverse play areas and } \\
\text { materials, even when the resources of the } \\
\text { institution are limited. }\end{array}$ & & & $\mathrm{x}$ \\
\hline S_LE02 & $\begin{array}{l}\text { Ich kann bei Kindern die Neugier auf Neues } \\
\text { wecken, auch wenn sie zunächst wenig } \\
\text { Interesse dafür zeigen. }\end{array}$ & $\begin{array}{l}\text { I can awaken children's curiosity about } \\
\text { new experiences, even if they show little } \\
\text { interest at first. }\end{array}$ & & & $\mathrm{x}$ \\
\hline S_LE04 & $\begin{array}{l}\text { Ich kann die Lernumgebung so gestalten, } \\
\text { dass alle Kinder der Gruppe passende } \\
\text { Herausforderungen finden, auch wenn die } \\
\text { Bedürfnisse sehr unterschiedlich sind. }\end{array}$ & $\begin{array}{l}\text { I can structure the learning environment in } \\
\text { such a way that all children in the group } \\
\text { find suitable challenges, even when their } \\
\text { needs are very different. }\end{array}$ & & & $\mathrm{x}$ \\
\hline
\end{tabular}

Note: $\mathrm{CP}=$ Child participation; $\mathrm{AL}=$ Child as Active Learner; $\mathrm{LE}=$ Learning Environment .

lations showed an exceptional model fit $\left(\chi^{2}=15.09 ; d f=15 ; \mathrm{CFI}=1\right.$; RMSEA = 0.005; SRMR = 0.032).

\section{Results}

Below we report results of the bivariate associations between study variables and differences between education settings. Further, we present the findings of the full structural model including the hypothesised mediation paths. Structural equation models were run using Mplus 7.11 (Muthén \& Muthén, 2012). Generalised Linear Models were run in IBM SPSS Statistics 21.

\subsection{Bivariate associations between professional background, teacher beliefs, and educational practice}

Structural equation models were run to estimate the latent bivariate associations between the study variables. All correlations between study variables are shown in Table 4. As expected self-efficacy, attitudes, and educational practice were significantly correlated with each other. For associations between professional background variables (i.e., length of training in early childhood education, domain-specific knowledge, professional experience, educational level) and self-efficacy, attitudes, and educational practice, results were more mixed: domain-specific knowledge was found to be positively associated with self-efficacy, attitudes, and educational practice, while the length of training in early childhood education was not associated with the other variables. Professional experience was significantly and positively associated with attitudes as well as with self-efficacy, but not with educational practice. Furthermore, educational level was significantly positively associated with attitudes alone.
For professional background, length of training in early childhood education correlated positively with domain-specific knowledge, professional experience as well as educational level. Furthermore, domain-specific knowledge was positively related to professional experience, but not to educational level. Professional experience correlated positively with educational level.

\subsection{Education setting differences}

Generalised Linear Models (GZLM) were used to investigate differences between participants working in different early education settings. Descriptive results are shown in Table 5. Three separate GZLMs were run with (1) self-efficacy, (2) attitudes and (3) childcentred educational practice as dependent variables. The setting was entered into the analyses as an independent categorical variable. The small subgroup of "other settings" is not considered in these analyses. Post-hoc tests were run pairwise using Bonferroni correction to adjust for type one error inflation.

Professionals from the different early educational settings showed significant differences in child-centred educational practice (see Table 5). Professionals providing family-based daycare reported significantly less child-centred educational practice than their professional colleagues working in centre-based daycare $(T$ $(139)=-2.95 ; p<0.05 ; d=-0.50)$. No other significant differences in child-centred educational practice were found.

Professionals from the different early education settings also differed significantly in their self-efficacy in terms of child-centredness (see Table 5). Again, professionals providing family-based daycare reported significantly lower self-efficacy compared to professionals working in centre-based daycare $(T(138)=-3.75 ; p<0.001$; $d=-0.64)$, as well as compared to professionals leading educa- 
Table 4

Correlations Among Study Variables.

\begin{tabular}{|c|c|c|c|c|c|c|}
\hline & 2 & 3 & 4 & 5 & 6 & 7 \\
\hline \multicolumn{7}{|l|}{ Child-centred orientation } \\
\hline 1. Educational practice & $0.61^{*}$ & $0.49^{*}$ & $0.28^{*}$ & 0.03 & 0.08 & 0.07 \\
\hline 2. Self-efficacy & - & $0.61^{*}$ & $0.31^{*}$ & 0.10 & $0.17^{*}$ & 0.12 \\
\hline 3. Attitudes & & - & $0.27^{*}$ & 0.09 & $0.22^{*}$ & $0.25^{*}$ \\
\hline \multicolumn{7}{|l|}{ Professional background } \\
\hline 4. Domain-specific knowledge & & & - & $0.19^{*}$ & $0.23^{*}$ & 0.07 \\
\hline 5. Training in early childhood education & & & & - & $0.44^{*}$ & $0.27^{*}$ \\
\hline 6. Professional experience & & & & & - & $0.22^{*}$ \\
\hline 7. Educational level & & & & & & - \\
\hline
\end{tabular}

${ }^{*} p<.05$.

Table 5

Descriptive Results by Educational Setting.

\begin{tabular}{|c|c|c|c|c|c|c|c|c|c|}
\hline & \multicolumn{2}{|c|}{ Total $(n=265)$} & \multicolumn{2}{|c|}{$\begin{array}{l}\text { Centre-based } \\
\text { daycare }(n=96)\end{array}$} & \multicolumn{2}{|c|}{$\begin{array}{l}\text { Family-based } \\
\text { daycare }(n=50)\end{array}$} & \multicolumn{2}{|c|}{$\begin{array}{l}\text { Educational } \\
\text { playgroups }(\mathrm{n}=86)\end{array}$} & \multirow[t]{2}{*}{ Wald $\chi^{2}$} \\
\hline & M & SD & M & SD & M & SD & M & SD & \\
\hline Self-efficacy & 4.29 & 0.46 & $4.34^{\mathrm{a}}$ & 0.46 & $4.04^{\mathrm{ab}}$ & 0.48 & $4.36^{\mathrm{b}}$ & 0.42 & $17.692(251)^{* * * *}$ \\
\hline Attitudes & 4.65 & 0.31 & 4.65 & 0.34 & 4.59 & 0.32 & 4.67 & 0.26 & n.s. \\
\hline Educational practice & 4.28 & 0.42 & $4.35^{\mathrm{a}}$ & 0.42 & $4.13^{\mathrm{a}}$ & 0.47 & 4.29 & 0.39 & $8.877(254)^{*}$ \\
\hline
\end{tabular}

a,b Significant differences between groups.

${ }^{*} p<0.05$.

$p<0.001$.

tional playgroups $(T(130)=-3.88 ; p<0.001 ; d=-0.68)$. No other significant differences in self-efficacy were found.

No significant differences between professionals working in different early educational settings were found for attitudes towards child-centredness.

\subsection{Mediation analyses}

Finally, the mediating role of attitudes and self-efficacy in the association between professional background and professionals' child-centred educational practice was tested, as well as between the early educational setting and professionals' child-centred practice.

In a first step, the direct effects were modelled. Professional background (domain-specific knowledge, training in early childhood education, professional experience, and educational level), group size (as a control variable), and educational setting (dummy coded) were modelled as predictors of the latent variables representing attitudes, self-efficacy, and educational practice. The effects of attitudes and self-efficacy on child-centred educational practice were also modelled. The model yielded an acceptable fit to the data $\left(\chi^{2}=97.828 ; d f=63 ; p<0.01 ; C F I=0.945 ;\right.$ RMSEA =0.046; SRMR = 0.041).

Self-efficacy was found to positively predict child-centred educational practice $(\beta=0.46 ; p<0.001)$. A higher degree of self-efficacy was related to a greater level of child-centred educational practice. Further, domain-specific knowledge was positively associated with self-efficacy ( $\beta=0.24, p<0.001$ ). The more domainspecific knowledge participants reported, the more self-efficacy in child-centredness they expressed. Educational setting differences were also found: family daycare providers were found to report significantly less self-efficacy $(\beta=-0.26 ; p<0.01)$ than caregivers in daycare centres. Finally, attitudes were positively associated with domain-specific knowledge ( $\beta=0.20 ; p<0.05)$, professional experience $(\beta=0.17, p<0.05)$, and educational level $(\beta=0.24, p<0.01)$.

Following on from the model with direct effects only, we tested our mediation hypotheses. As attitudes were not significantly associated with educational practice, we only tested self-efficacy as potential mediator. First, we tested whether self-efficacy medi- ates the association between domain-specific knowledge and professionals' child-centred educational practice. We then tested whether self-efficacy mediates the association between early educational setting and professionals' child-centred educational practice. Thus, the full model was extended by testing for these two indirect effects. Table 6 shows the standardised parameters of the model including both direct and indirect effects. The standardised solution of the model can be found in Fig. 1. The analysis confirmed the two mediation paths to be significant. Self-efficacy was found to fully mediate the impact of domain-specific knowledge on professionals' educational practice. Self-efficacy also fully mediated the impact of early educational setting on professionals' educational practice.

\section{Discussion}

The present study investigated whether self-efficacy and attitudes (i.e., teacher beliefs) mediate the impact of professional background on educational practice. Child-centred educational practice was positively associated with domain-specific knowledge, and was also more frequent in centre-based than in family-based childcare. Most importantly, self-efficacy was found to mediate the impact of domain-specific knowledge as well as early educational setting on professionals' educational practice. Thus, our study emphasises the role of professionals' self-efficacy in delivering high-quality childcare and education in early childhood.

\subsection{Professional background and educational practice}

As hypothesised, professional background was associated with child-centred educational practice. However, some facets of professional background were more relevant than others. Domain-specific knowledge was positively related to child-centred educational practice and to self-efficacy and attitudes, while length of training in early childhood education was not. This result suggests that the content of knowledge or training matters more when it comes to child-centredness than the simple length of training. However, we do not know whether the curriculum of the training emphasised child-centred teaching approaches. In our study, 
Table 6

Mediation paths: Standardised total, total indirect, specific indirect and direct effects.

\begin{tabular}{|c|c|c|c|c|}
\hline & $\beta$ & S.E. & $\beta / S . E$. & $p$-value \\
\hline \multicolumn{5}{|l|}{ Path from KNOW to PRAC } \\
\hline Total & 0.24 & 0.07 & 3.27 & 0.001 \\
\hline Total indirect & 0.15 & 0.04 & 3.34 & 0.001 \\
\hline \multicolumn{5}{|l|}{ Specific indirect } \\
\hline KNOW - ATT - PRAC & 0.04 & 0.03 & 1.23 & 0.219 \\
\hline KNOW - EFF - PRAC & 0.11 & 0.04 & 2.57 & 0.010 \\
\hline \multicolumn{5}{|l|}{ Direct } \\
\hline KNOW - PRAC & 0.10 & 0.07 & 1.35 & 0.176 \\
\hline \multicolumn{5}{|l|}{ Path from FAM to PRAC } \\
\hline Total & -0.2 & 0.09 & -2.16 & 0.031 \\
\hline Total indirect & -0.14 & 0.05 & -2.60 & 0.009 \\
\hline \multicolumn{5}{|l|}{ Specific indirect } \\
\hline FAM - ATT - PRAC & -0.02 & 0.02 & -0.87 & 0.382 \\
\hline FAM - EFF - PRAC & -0.12 & 0.05 & -2.42 & 0.015 \\
\hline \multicolumn{5}{|l|}{ Direct } \\
\hline FAM - PRAC & -0.06 & 0.09 & -0.72 & 0.474 \\
\hline
\end{tabular}

Note: PRAC = Educational practice; ATT = Attitudes; EFF= Self-efficacy; FAM = Family-based daycare.

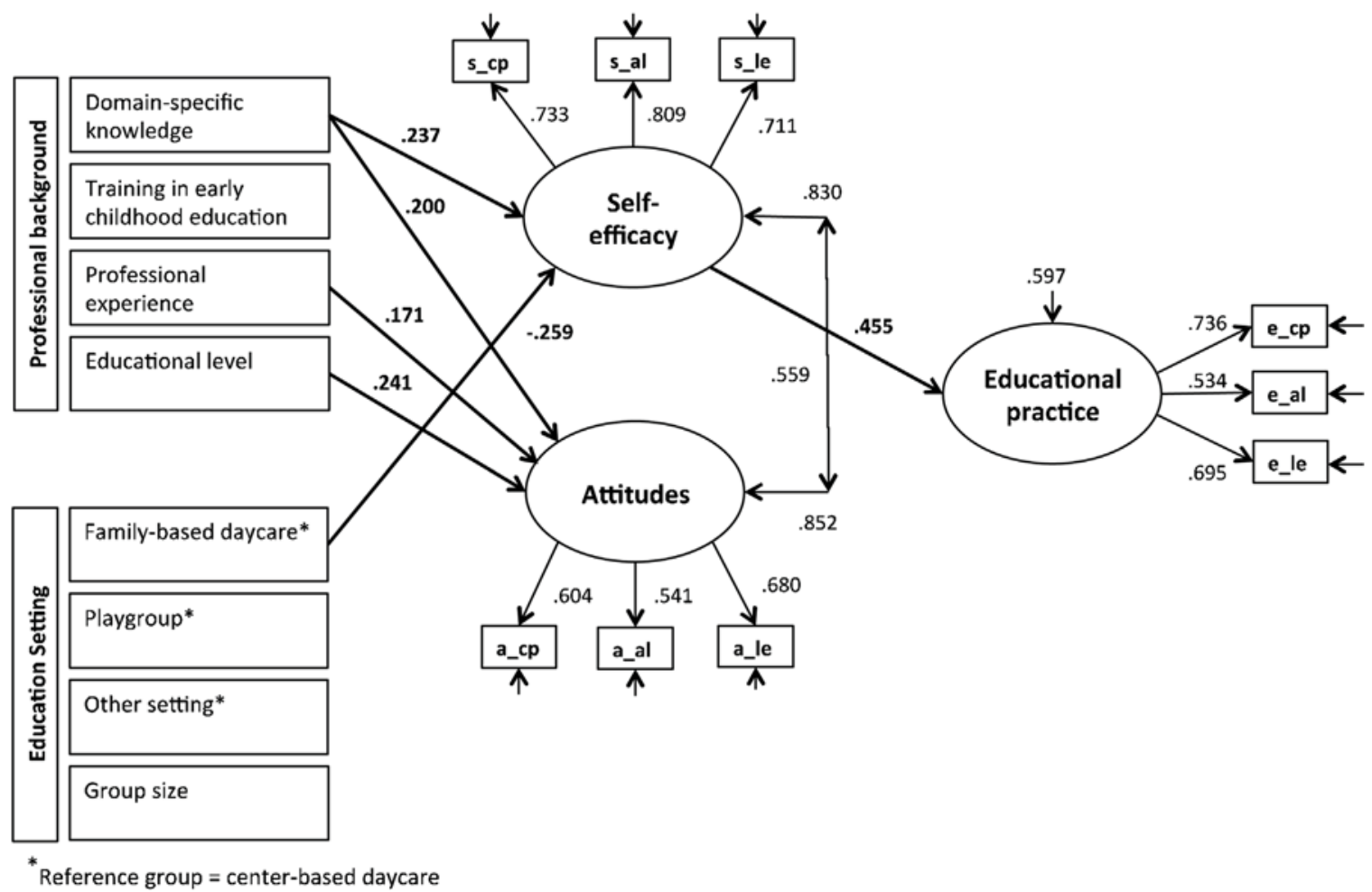

Fig. 1. Standardised solution of the structural equation model. Figure shows significant paths only.

Note: $s_{-}=$Self-efficacy, $a_{-}=$Attitudes, $e_{-}=$Educational practice; $c p=$ Child participation; $a l=$ Child as active learner; le = Learning environment.

the domain-specific knowledge score was high if participants were familiar with the Orientierungsrahmen, a framework that strongly promotes and emphasises child-centred practices (Wustmann Seiler \& Simoni, 2012). Thus, we did not assess directly whether the participants in fact knew the relevant child development theories and teaching approaches related to child-centredness, but merely whether and how intensively they had engaged with the reference document (e.g., through reading, discussing, attending specific workshops, and watching demonstration videos that can be found at www.kinder-4.ch). Moreover, participants' reports of their domain-specific knowledge might also partly reflect participants' personal epistemology, that is the beliefs they hold about knowing and knowledge (Muis \& Duffy, 2013), rather than their real knowledge. Nevertheless, domain-specific knowledge showed robust and moderately sized associations with educational practice and self-efficacy.

In contrast to our expectations, professional experience was not associated with educational practice and self-efficacy, but with attitudes. In part, this is in contrast with other studies which showed significant associations between professional experience and a more positive (observed) teaching practice (Jeon et al., 2015) and higher self-efficacy (Bullock et al., 2015; Fives \& Buehl, 2009). It might be that professional level shows a non-linear relationship with self-efficacy (Klassen \& Chiu, 2010).

A higher general educational level was associated with more child-centred attitudes, but not with the corresponding educational practice or self-efficacy beliefs. We might assume that having a certain attitude promotes the corresponding behaviour, so it is surprising that a significant relationship can be found with attitudes 
but not with practice, especially since we actually found a relationship between attitudes and educational practice in our bivariate analyses described above. On the other hand, previous studies have also shown that raising the educational level (e.g., requiring a Bachelor's degree) is not an effective strategy for improving teaching quality (Early et al., 2007).

\subsection{The role of teacher beliefs in educational practice}

As hypothesised, teacher beliefs were significantly and positively associated with educational practice. The multivariate analyses showed that self-efficacy is a stronger predictor of early childhood professionals' behaviour than their attitudes. This finding is in line with our hypothesis. According to Fives and Buehl (2012), self-efficacy beliefs may act as a guide for immediate action, whereas beliefs related to teaching approach (i.e., attitudes) may act as a frame for the interpretation of relevant situations. The impact of self-efficacy was stronger as it guides and motivates concrete actions, whereas attitudes shape the perception, interpretation and conceptualisation of events or situations (Fives \& Buehl, 2012). These findings are in contrast to the study by Hughes-Belding et al. (2012), which showed that attitude towards modernity was a stronger predictor of family daycare providers' educational practice than their perceived ability (i.e., self-efficacy) in their teaching practices, knowledge, and behaviour management. In contrast to this and other studies in the field, we assessed the constructs self-efficacy, attitudes and practice in relation to the same domain; that is all scales covered the construct of childcentredness (i.e., child participation, learning environment, and child as an active learner). As this is the first study in the early education field to show these specific associations, further studies replicating our results are necessary.

The scale we used to assess self-efficacy in the present study was specific to child-centred educational practice. It would be interesting to include measures of general self-efficacy in further studies to investigate whether general, as opposed to specific, self-efficacy is a valid predictor of educational practice. Moreover, recent research found personality traits to be associated with self-efficacy (Bullock et al., 2015; Jamil, Downer, \& Pianta, 2012). Contextual factors such as collegiality within a team and job satisfaction might also be considered (Hur, Jeon, \& Buettner, 2015). Further studies should therefore include personality and contextual measures along with measures of professional background in order to deepen our understanding of how self-efficacy can be strengthened in early education and care professionals.

The cultural background is also important when interpreting our results. Our study was conducted in Switzerland and some of the findings might be specific to this country and its organisation of early care and educational settings. In particular, a child-centred approach in early education and care is in line with the current practice in Switzerland. Furthermore, public opinion does not support formal education, teacher-initiated lessons or the practising of skills in children under the age of four. The current understanding of early education is reflected in the Swiss reference document (Orientierungsrahmen), which was created through assembling research evidence, theoretical accounts, and the opinions of experts and practitioners in the field (Wustmann Seiler \& Simoni, 2012). The high mean scores of our scales - especially for attitudes - also demonstrate a high level of agreement with a child-centred teaching approach in our sample. These results indicate that in early childhood education and care in Switzerland, a child-centred approach is favoured, at least at the attitudinal level.

Our study suggests that strengthening self-efficacy might be a way to promote better educational practice. Acquiring knowledge about a child-centred teaching approach had an impact on selfefficacy. As the contents of the reference documents are in line with the way many educators work and/or with their attitudes, knowledge of and reading an official reference document that supports their practice and attitude might have a reinforcing effect and strengthen their self-efficacy in terms of child-centred educational practice. For instance, in a study by Suk Lee et al. (2006) teachers' learning of new teaching practices (i.e., scaffolding) was improved when the associated beliefs (i.e., in developmentally appropriate practices) were congruent with their existing beliefs. If the educational practice promoted in the reference document was not congruent with educators' practice and attitudes, it would be less likely that knowing about it would strengthen their self-efficacy.

\subsection{Educational practice and teacher beliefs in different educational settings}

In line with our predictions, we found differences between educators in the different educational settings. Professionals working in centre-based daycare or leading an educational playgroup reported more domain-specific knowledge and more months of training in early childhood education than professionals providing family-based daycare. These differences were found to be independent of professional background. Further, professionals providing family-based daycare reported significantly lower scores on childcentred educational practice than their colleagues working in centre-based daycare. This is somewhat surprising, since we might assume that taking children's individual developmental level and needs into account, i.e., child-centred educational practice, might be easier when fewer children are present. More importantly, we found that family care providers also feel less self-efficacious than their colleagues working in centre-based care or educational playgroups; the effect on educational practice for family care providers was mediated by self-efficacy.

No difference between early educational settings was found for attitudes. Several researchers have found family care providers to hold more traditional attitudes than professionals working in centre-based care (e.g., Dowsett, Huston, Imes, \& Gennetian, 2008). However, we were not able to support this finding, as all participants reported highly positive attitudes towards child-centredness. We could therefore conclude that child-centred practice fits the picture that professionals wish to promote when thinking about good education and care for young children. Nevertheless, whether actions follow beliefs seems to depend on self-efficacy. Our study showed that although family daycare providers endorse childcentred attitudes, they actually engage in those activities less frequently because they are less self-efficacious in terms of childcentredness. Self-efficacy is believed to grow over time, if a person has the chance to experience performance accomplishments and to learn from vicarious experiences, is verbally influenced by others, and is able to see physiological responses to a challenging situation as normal rather than as indicating lack of ability (Bandura, 1977). Family daycare providers often lack the opportunity to gain vicarious experience, since they care for the children alone. Likewise, other than occasional comments from parents they do not receive any verbal feedback from colleagues on their educational practice and therefore have to persuade and encourage themselves in order to become self-efficacious.

It is important to note that the enactment of beliefs depends on the context (Fives \& Buehl, 2012). In our study we investigated whether we could find differences between educational settings. Further studies should consider context (such as setting or working conditions) as potential moderators of the associations between teacher beliefs and educational practice (see for example, SusmanStillman, Pleuss, \& Englund, 2013). 


\subsection{Strengths and limitations}

For the current study, we developed a new questionnaire. The results demonstrate the strong construct validity of our questionnaire, as confirmatory factor analyses supported our hypothesised factorial structure. The significant association between domainspecific knowledge (knowledge of the Orientierungsrahmen as a child-centred framework) and our questionnaire is a further indicator of the face validity of our questionnaire. Further studies have yet to be conducted to establish the validity of the questionnaire in other populations and cultures.

However, the questionnaire is a self-report measure and therefore we cannot rule out social desirability being reflected in the answers given. In the course of item selection, we retained only the strongest items. Unfortunately, none of the negatively poled items, which were created to identify the response patterns of social desirability, met our final selection criteria. As educational practice was only measured through self-report, further studies must investigate whether professionals' self-reported educational practice is consistent with their observed educational practice. Another limitation of our results is that participation in the online survey was voluntary. Since the time needed to complete the survey was relatively long, it can be assumed that participants who completed it were highly motivated and particularly interested in the subject of the survey. They therefore may not be a representative sample of professionals working in early education and care in Switzerland. Thus, the present finding may have limited generalisability and must be interpreted with caution. Furthermore, we only collected cross-sectional data, so no conclusions can be drawn about stability or causal ordering of the associations that were examined.

\subsection{Practical implications}

Our study showed differences between centre- and familybased caregivers that may have important practical implications. Family caregivers in general have completed little or no training in early childhood education and domain-specific knowledge. They were also found to be less self-efficacious than their colleagues working in educational playgroups or centre-based care. All in all, our study showed that the group of family, early childhood daycare providers might optimise their child-centred educational practice with specific training, support, or other measures that increase their knowledge and therefore also their self-efficacy.

Our study demonstrated that self-efficacy is a stronger predictor of professionals' behaviour than attitudes. Therefore, training and other professional development measures aiming to enhance childcentredness should focus on improving professionals' self-efficacy, because focusing on attitudes seems to be less effective. Courses and workshops should also include methods of self-reflection, as this may be an important mechanism through which teacher beliefs could be altered (Fives \& Buehl, 2012).

Professionals' self-efficacy not only increases the quality of educational practice in favour of young children, but can also be seen as a factor of more general importance for a high professional standard. To feel self-efficacious is a resource of well-being that enables professionals to handle everyday difficulties with more confidence and calm, which in turn allows them to perform best. In sum, our study suggests that promoting domain-specific knowledge may have an impact on educators' child-centred practice by increasing their self-efficacy.

\section{Acknowledgements}

The study was financially supported by the Jacobs Foundation (grant to the first author). Many thanks to Isabell Eckert, Yin-Ru
Lim, and Patricia Müller who contributed to developing the questionnaire.

\section{References}

Bandura, A. (1977). Self-efficacy: toward a unifying theory of behavioral change. Psychological Review, 84(2), 191-215

Bandura, A. (1986). Social foundations of thought and action: a social cognitive theory. Englewood Cliffs, NJ: Prentice-Hall, Inc.

Bandura, A. (1997). Self-efficacy: the exercise of control. Worth Publishers.

Bullock, A., Coplan, R. J., \& Bosacki, S. (2015). Exploring links between early childhood educators' psychological characteristics and classroom management self-efficacy beliefs. Canadian Journal of Behavioural Science/Revue Canadienne Des Sciences Du Comportement, 47(2), 175-183. http://dx.doi.org/10.1037/ a0038547

Bundesamt für Statistik. (2014). Familien, Haushalte: Daten. Indikatoren: Europäischer Vergleich. http://www.bfs.admin.ch/bfs/portal/de/index/ themen/01/04/blank/key/04/04.html Accessed 16.12.15.

Charlesworth, R., Hart, C. H., Burts, D. C., Thomasson, R. H., Mosley, J., \& Fleege, P. O. (1993). Measuring the developmental appropriateness of kindergarten teachers' beliefs and practices. Early Childhood Research Quarterly, 8(3), 255-276.

Copple, C., \& Bredekamp, S. (2010). Developmentally appropriate practice in early childhood programs serving children from birth through age 8. Washington, D.C National association for education of young children.

Dowsett, C. J.. Huston, A. C. Imes, A. E., \& Gennetian, L. (2008). Structural and process features in three types of child care for children from high and low income families. Early Childhood Research Quarterly, 23(1), 69-93. http://dx.doi. org/10.1016/j.ecresq.2007.06.003

Early, D. M., Maxwell, K. L., Burchinal, M., Alva, S., Bender, R. H., Bryant, D. . . . \& Zill, N. (2007). Teachers' education, classroom quality, and young children's academic skills: Results from seven studies of preschool programs. Child Development, 78(2), 558-580. http://dx.doi.org/10.1111/j.1467-8624.2007. 01014.x

Fantuzzo, J., Perlman, S., Sproul, F., Minney, A., Perry, M. A., \& Li, F. (2012). Making visible teacher reports of their teaching experiences: The early childhood teacher experiences scale. Psychology in the Schools, 49(2), 194-205. http://dx. doi.org/10.1002/pits.20623

Fives, H., \& Buehl, M. M. (2009). Examining the factor structure of the teachers' sense of efficacy scale. The Journal of Experimental Education, 78(1), 118-134. http://dx.doi.org/10.1080/00220970903224461

Fives, H., \& Buehl, M. M. (2012). Spring cleaning for the messy construct of teachers' beliefs: What are they? Which have been examined? What can they tell us? In K. R. Harris, S. Graham, \& T. Urdan (Eds.), APA educational psychology handbook: Individual differences and cultural and contextual factors (Vol. 2) (pp. 471-499). Washington: American Psychological Association. http://content. apa.org/books/13274-019

Fukkink, R. G., \& Lont, A. (2007). Does training matter? A meta-analysis and review of caregiver training studies. Early Childhood Research Quarterly, 22(3), 294-311. http://dx.doi.org/10.1016/j.ecresq.2007.04.005

Guo, Y., Piasta, S. B., Justice, L. M., \& Kaderavek, J. N. (2010). Relations among preschool teachers' self-efficacy, classroom quality, and children's language and literacy gains. Teaching and Teacher Education, 26(4), 1094-1103. http://dx. doi.org/10.1016/j.tate.2009.11.005

Hughes-Belding, K., Hegland, S., Stein, A., Sideris, J., \& Bryant, D. (2012). Predictors of global quality in family child care homes: Structural and belief characteristics. Early Education and Development, 23(5), 697-712. http://dx.doi. org/10.1080/10409289.2011.574257

Hur, E., Buettner, C. K., \& Jeon, L. (2015). The association between teachers' child-centered beliefs and children's academic achievement: The indirect effect of children's behavioral self-regulation. Child E Youth Care Forum, 44(2), 309-325. http://dx.doi.org/10.1007/s10566-014-9283-9

Hur, E., Jeon, L., \& Buettner, C. K. (2015). Preschool teachers' child-centered beliefs: Direct and indirect associations with work climate and job-related wellbeing. Child E' Youth Care Forum, http://dx.doi.org/10.1007/s10566-015-9338-6

Jamil, F. M., Downer, J. T., \& Pianta, R. C. (2012). Association of pre-service teachers' performance, personality, and beliefs with teacher self-efficacy at program completion. Teacher Education Ouarterly, 39(4), 119-138.

Jeon, L., Buettner, C. K., \& Hur, E. (2015). Preschool teachers' professional background, process quality, and job attitudes: A person-centered approach. Early Education and Development, http://dx.doi.org/10.1080/10409289.2016. 1099354

Kishton, J. M., \& Widaman, K. F. (1994). Unidimensional versus domain representative parceling of questionnaire items: An empirical example. Educational and Psychological Measurement, 54(3), 757-765. http://dx.doi.org/ $10.1177 / 0013164494054003022$

Klassen, R. M., \& Chiu, M. M. (2010). Effects on teachers' self-efficacy and job satisfaction: Teacher gender, years of experience, and job stress. Journal of Educational Psychology, 102(3), 741-756. http://dx.doi.org/10.1037/a0019237

La Paro, K. M., Hamre, B. K., \& Pianta, R. C. (2012). Classroom assessment scoring system (CLASS) manual, toddler. Baltimore, Maryland: Brookes Publishing Co, Inc.

Little, T. D., Cunningham, W. A., Shahar, G., \& Widaman, K. F. (2002). To parcel or not to parcel: Exploring the question, weighing the merits. Structural Equation Modeling, 9(2), 151-173. 
McMullen, M. B. Elicker J. Goetze C . Huang $\mathrm{H}_{\text {. }} \mathrm{H}$. Lee, S.-M., Mathers, C., . . \& \& Yang, H. (2006). Using collaborative assessment to examine the relationship between self-reported beliefs and the documentable practices of preschool teachers. Early Childhood Education Journal, 34(1), 81-91. http://dx.doi.org/10. 1007 /s10643-006-0081-3

Muis, K. R., \& Duffy, M. C. (2013). Epistemic climate and epistemic change: Instruction designed to change students' beliefs and learning strategies and improve achievement. Journal of Educational Psychology, 105(1), 213-225. http://dx.doi.org/10.1037/a0029690

Muthén, L. K., \& Muthén, B. O. (2012). Mplus (Version 7). Los Angeles, CA: Muthén \& Muthén.

OECD. (2009). Creating effective teaching and learning environments: first results from TALIS. Paris: OECD.

Pajares, M. F. (1992). Teachers' beliefs and educational research: Cleaning up a messy construct. Review of Educational Research, 62(3), 307-332. http://dx.doi. org/10.3102/00346543062003307

Perren, S., \& Herrmann, S. (2014). ORA-Fragebogen. Ein Instrument zur Erfassung von pädagogischen Vorstellungen und pädagogischer Praxis im Frühbereich. Unpublished questionnaire. University of Konstanz/Pädagogische Hochschule Thurgau.

Perren, S., Frei, D., \& Herrmann, S. (2016). Pädagogische Qualität in frühkindlichen Bildungs- und Betreuungseinrichtungen in der Schweiz: Erste Erfahrungen und Befunde mit dem CLASS toddler Beobachtungsverfahren. Frühe Bildung, 5(1), 3-12.

Ross, J., \& Bruce, C. (2007). Professional development effects on teacher efficacy: Results of randomized field trial. The Journal of Educational Research, 101(1), 50-60. http://dx.doi.org/10.3200/JOER.101.1.50-60

Schwarzer, R. (Ed.). (1992). Self-efficacy: thought control of action. Washington: Taylor \& Francis.

Sheridan, S. M., Edwards, C. P., Marvin, C. A., \& Knoche, L. L. (2009). Professional development in early childhood programs: Process issues and research needs. Early Education E Development, 20(3), 377-401. http://dx.doi.org/10.1080/ 10409280802582795

Stamm, M. (2009). Frühkindliche Bildung in der Schweiz. Eine Grundlagenstudie im Auftrag der UNESCO-Kommission Schweiz (Monograph). Fribourg: University of Fribourg. http://edudoc.ch/record/31203/files/FBBE.pdf

Stipek, D. J., \& Byler, P. (1997). Early childhood education teachers: Do they practice what they preach? Early Childhood Research Quarterly, 12(3), 305-325. http://dx.doi.org/10.1016/S0885-2006(97)90005-3
Suk Lee, Y., Baik, J., \& Charlesworth, R. (2006). Differential effects of kindergarten teacher's beliefs about developmentally appropriate practice on their use of scaffolding following inservice training. Teaching and Teacher Education, 22(7), 935-945. http://dx.doi.org/10.1016/j.tate.2006.04.041

Susman-Stillman, A., Pleuss, J., \& Englund, M. M. (2013). Attitudes and beliefs of family- and center-based child care providers predict differences in caregiving behavior over time. Early Childhood Research Quarterly, 28(4), 905-917. http:// dx.doi.org/10.1016/j.ecresq.2013.04.003

Swackhamer, L. E., Koellner, K., Basile, C., \& Kimbrough, D. (2009). Increasing the self-efficacy of inservice teachers through content knowledge. Teacher Education Quarterly, 36(2), 63-78.

Todd Brown, E. (2005). The influence of teachers' efficacy and beliefs regarding mathematics instruction in the early childhood classroom. Journal of Early Childhood Teacher Education, 26(3), 239-257. http://dx.doi.org/10.1080/ 10901020500369811

Tout, K., Zaslow, M., \& Berry, D. (2005). Quality and qualifications: Links between professional development and quality in early care and education settings. In M. Zaslow, \& I. Martinez-Beck (Eds.), Critical issues in early childhood professional development. Baltimore, MD: Brookes Publishing Co., Inc.

Tschannen-Moran, M., Hoy, A. W., \& Hoy, W. K. (1998). Teacher efficacy: Its meaning and measure. Review of Educational Research, 68(2), 202-248. http:// dx.doi.org/10.3102/00346543068002202

Weltzien, D. (2011). Von der Beobachtung in den Dialog. In U. Stenger, \& S. Kägi (Eds.), Forschung in Feldern der Frühpädagogik (1st ed., Vol. 2, pp. 213-224). Hohengehren: Scheider.

Wustmann Seiler, C., \& Simoni, H. (2012). Orientierungsrahmen für frühkindliche Bildung, Betreuung und Erziehung in der Schweiz. Erarbeitet vom Marie Meierhofer Institut für das Kind, erstellt im Auftrag der Schweizerischen UNESCO-Kommission und des Netzwerks Kinderbetreuung Schweiz. Zurich. http:/ www.fruehkindliche-bildung.ch/projekte/orientierungsrahmen.html

Zaslow, M., Tout, K., Halle, T., Whittaker, J. V., \& Lavelle, B. (2010). Toward the identification of features of effective professional development for early childhood educators. Washington: U.S. Department of Education. http://www.ed.gov/ about/offices/list/opepd/ppss/reports.html 